\title{
A REVIEW OF BOTANY, THERAPEUTIC VALUE, PHYTOCHEMISTRY, AND PHARMACOLOGY OF CUSSONIA PANICULATA
}

\author{
ALFRED MAROYI* \\ Department of Botany, Medicinal Plants and Economic Development Research Centre, University of Fort Hare, Private Bag X1314, \\ Alice 5700, South Africa. Email: amaroyi@ufh.ac.za
}

Received: 04 June 2019, Revised and Accepted: 01 July 2019

\begin{abstract}
Cussonia paniculata is a small tree widely used as herbal medicine throughout its distributional range in southern Africa. This study is aimed at providing a critical review of the botany, biological activities, phytochemistry, and medicinal uses of $C$. paniculata. Documented information on the botany, biological activities, medicinal uses, and phytochemistry of $C$. paniculata was collected from several online sources which included BMC, Scopus, SciFinder, Google Scholar, Science Direct, Elsevier, PubMed, and Web of Science. Additional information on the botany, biological activities, phytochemistry, and medicinal uses of $C$. paniculata was gathered from pre-electronic sources such as book chapters, books, journal articles, and scientific publications sourced from the University library. This study showed that the bark, fruits, leaves, roots, and stems of $C$. paniculata are used as emetic, immune booster, and herbal medicine for dysmenorrhea, intestinal parasites and worms, mental problems, boils, shingles and skin diseases, indigestion and stomach complaints, sores, and wounds. Phytochemical compounds identified from the leaves of $C$. paniculata include acetylated triterpene glycosides, unacetylated triterpene glycosides, flavonoid, steroidal saponin, and triterpenoid saponins. Pharmacological research revealed that $C$. paniculata extracts have analgesic, antibacterial, anticancer, anti-inflammatory, antiplasmodial, antiprotozoan, A $\beta 42$ protein reduction, and cytotoxicity activities. Future research should focus on evaluating the phytochemical, pharmacological, and toxicological properties of $C$. paniculata crude extracts as well as compounds isolated from the species.
\end{abstract}

Keywords: Araliaceae, Cussonia paniculata, Ethnopharmacology, Herbal medicine, Indigenous pharmacopeia.

(C) 2019 The Authors. Published by Innovare Academic Sciences Pvt Ltd. This is an open access article under the CC BY license (http://creativecommons. org/licenses/by/4. 0/) DOI: http://dx.doi.org/10.22159/ajpcr.2019.v12i9.34434

\section{INTRODUCTION}

Cussonia paniculata Eckl. and Zeyh. is a member of the Araliaceae or ginseng or ivy family. Ginseng is a common name for several herbaceous plants used in traditional medicines such as Asian ginseng (Panax ginseng C.A. Meyer) [1-6], American ginseng (Panax quinquefolius L.) [4,7-14], and Japanese ginseng (Panax japonicus (T.Nees) C.A. Meyer) [4,15-21]. Ivy is a common name for Hedera L. species grown as ornamental plants and house plants throughout the world [22-24]. Several Hedera species are used as herbal medicines for respiratory, skin problems, and other health-related conditions [25-32]. Hedera species are also characterized by several phytochemical and biological activities which include antimicrobial, antiinflammatory, antiarthritic, antioxidant, antispasmodic, antiallergic, and antitumor activities [29,33-39]. The genus Cussonia Thunb. comprises about 22 species which are mainly trees or shrubs or occasionally subshrubs recorded in grasslands, woodlands, and forests of sub-Saharan Africa, the Arabian Peninsula (Yemen), and the Comoro Islands [40-46]. C. paniculata is widely used as a decorative and ornamental plant, as the species is frost-resistant and therefore recommended for rockeries, bonsai, and other gardens [42,47-55]. C. paniculata is domesticated in home gardens in South Africa [56], and the thick tuberous roots are peeled and eaten raw as an emergency food, as a source of water or snack in South Africa and Swaziland [57-59]. In South Africa, research by Makunga et al. [60] showed that the flowers, leaves, and roots of C. paniculata are used in the production of essence and tinctures. Local communities in the Eastern Cape province in South Africa described C. paniculata as "rare" in the Eastern thorn bushveld [61], an observation which has important implications for conservation and sustainable use of the species. It is against this background that this study was undertaken aimed at appraising the botany, medicinal uses, phytochemistry, and biological activities of $C$. paniculata.

\section{TAXONOMY AND BOTANICAL DESCRIPTION OF C. PANICULATA}

The genus name Cussonia is in honor of Pierre Cusson (1727-1783), a French botany professor at the University of Montpellier who specialized in the plant group Umbrelliferae $[50,62,63]$. The specific name "paniculata" refers to the paniculate or branched inflorescence which terminates the growth of the species' branches. The English common name of $C$. paniculata is "mountain cabbage tree," mainly because the species is associated with dry stony hills and the thick, often blue-green leaves resemble those of a cabbage (Brassica oleracea L.) [49]. The leaves of $C$. paniculata are gray-green or blue-green in color which is probably due to the thick waxy layers on the leaves. These waxy layers are believed to protect the leaves from severe frost in winter [49]. Two subspecies of $C$. paniculata are recognized subsp. paniculata and subsp. sinuata (Reyneke and Kok) De Winter [64]. The subsp. paniculata is characterized by entire leaflet margins, confined to the southern Karoo, Eastern Cape, KwaZulu-Natal, Northern Cape, and Western Cape provinces of South Africa at an altitude ranging from $300 \mathrm{~m}$ to $2000 \mathrm{~m}$ above the sea level $[41,64]$. The subsp. sinuata is characterized by shallowly to deep lobed and waxy (sinuate) leaflet margins and widely distributed and recorded in Botswana, Lesotho, Swaziland, the Free State, Gauteng, KwaZulu-Natal, Limpopo, Mpumalanga, and North West provinces of South Africa at an altitude ranging from $900 \mathrm{~m}$ to $1980 \mathrm{~m}$ above the sea level $[41,64]$. However, most ethnobotanical and ethnopharmacological literature do not separate $C$. paniculata into specific subspecies but rather to C. paniculata sensu lato, and this is the approach that has been adopted in this study. Synonyms associated with $C$. paniculata include $C$. paniculata Eckl. and Zeyh. var. paniculata and C. paniculata Eckl. and Zeyh. var. sinuata Reyneke and Kok. [64].

C. paniculata is an evergreen small tree with a sturdy trunk which is sparsely branched, rarely exceeding $5 \mathrm{~m}$ in height $[41,63,65-68]$. The stem is reddish gray to gray, rough, corky, swollen at the base and roughly $3.5 \mathrm{~cm}$ in diameter, the branches marked with prominent leaf scars as the species usually sheds old leaves while new flush of leaves are being produced. The branches have a mop-like crown of leathery, green, frequently blue-green leaves, composed of several leaflets on short stalks springing from the same point at the end of a stout common stalk. The leaves are bi-digitate, oblong in shape, apex and base tapering, margin 
sparsely to distinctly toothed. The flowers are a branched panicle of spikes which are greenish yellow in color. The fruits are fleshy, almost globose in shape, pale purplish in color, and closely clustered along the spikes. $C$. paniculata has been recorded in Botswana, Lesotho, South Africa, and Swaziland $[41,63,66-68]$ in bushveld, wooded grassland, usually in rocky places at an altitude ranging from $300 \mathrm{~m}$ to $2000 \mathrm{~m}$ above the sea level [64].

\section{MEDICINAL USES OF C. PANICULATA}

The bark, fruits, leaves, roots, and stems of $C$. paniculata are used as herbal medicines against 32 human diseases in southern Africa (Table 1). C. paniculata is mainly used as emetic, immune booster, and herbal medicine for dysmenorrhea, intestinal parasites and worms, mental problems, boils, shingles and skin diseases, indigestion and stomach complaints, sores, and wounds (Fig. 1). In Lesotho, the leaves of $C$. paniculata are mixed with those of Searsia divaricata (Eckl. and Zeyh.) Moffett and Scabiosa columbaria L. as herbal medicine for menstrual problems [69].

\section{PHYTOCHEMISTRY OF C. PANICULATA}

Several researchers such as Dovgii et al. [93], Grishkovets et al. [94], Adedapo et al. [95], and Thakur et al. [76] identified acetylated triterpene glycosides, unacetylated triterpene glycosides, flavonoid, steroidal saponin, and triterpenoid saponins from the leaves of C. paniculata (Table 2). Some of these phytochemical compounds may be responsible for the pharmacological properties associated with C. paniculata. For example, research by Panche et al. [96] revealed that flavonoids are associated by acetylcholinesterase, antioxidant, steroid-genesis modulating, xanthine oxidase modulating, countering antibiotic resistance, and disease-combating activities. Research by Careaga et al. [97] and Bahrami and Franco [98] showed that acetylated triterpene glycosides have induction of caspase, antiproliferative, apoptosis, hemolytic, cytotoxicity, anticancer, antifungal, and antibacterial properties. While saponins have demonstrated antiviral, anti-inflammatory, hepatoprotective, anti-ulcer, antibacterial, hypoglycemic, anti-fertility, anticancer, antimalarial, anthelmintic, and antioxidant activities [99-103].

\section{BIOLOGICAL ACTIVITIES OF C. PANICULATA EXTRACTS}

Biological activities of $C$. paniculata extracts include analgesic [95], antibacterial [104], anticancer [105,106], anti-inflammatory [52,75,95], antiplasmodial [52,75,104], antiprotozoan [104], Aß42 protein reduction [76], and cytotoxicity [104] activities.

\section{Analgesic activities}

Adedapo et al. [95] evaluated the analgesic activities of aqueous extract of the stem bark of $C$. paniculata using the formalin test by treating male Wistar rats with $50 \mathrm{mg} / \mathrm{kg}, 100 \mathrm{mg} / \mathrm{kg}$, and $200 \mathrm{mg} / \mathrm{kg}$ of extract; $10 \mathrm{mg} / \mathrm{kg}$ of indomethacin; and $2 \mathrm{ml} / \mathrm{kg}$ of normal saline, and the licking time and frequency of the injected paw were recorded for $30 \mathrm{~min}$. In the acetic acid-induced writhing model, the extract showed a good analgesic effect characterized by reduction in the number of writhes when compared to the control. The extract caused dose-dependent decrease of licking time and licking frequency in rats injected with $2.5 \%$ formalin, signifying its analgesic effect [95].

\section{Antibacterial activities}

De Villiers et al. [104] evaluated antibacterial activities of aqueous and methanol leaf extracts of $C$. paniculata subsp. paniculata and C. paniculata subsp. sinuata against Enterococcus faecalis, Escherichia coli, Neisseria gonorrhoeae, Staphylococcus aureus, and Pseudomonas aeruginosa using the microplate bioassay with ciprofloxacin $(0.01 \mathrm{mg} / \mathrm{mL})$ as a positive control. The extract exhibited activities with minimum inhibitory concentration values ranging from $0.3 \mathrm{mg} / \mathrm{mL}$ to $16.0 \mathrm{mg} / \mathrm{mL}$ [104].

\section{Anticancer activities}

Fouché et al. [105] evaluated anticancer activities of dichloromethane leaf extracts of $C$. paniculata against sixty human cancer cell lines organized into subpanels representing leukemia, melanoma and cancer of the lung, colon, kidney, ovary, and central nervous system. The extracts exhibited a moderate growth inhibition of above $50 \%$ for two or more of the cell lines $\left(\mathrm{GI}_{50}\right)$ with values ranging from $>0 \mu \mathrm{g} / \mathrm{mL}$ to $1.1 \mu \mathrm{g} / \mathrm{mL}$ [105]. Similarly, Fouché et al. [106] evaluated anticancer

Table 1: Medicinal uses of Cussonia paniculata

\begin{tabular}{|c|c|c|c|}
\hline Medicinal use & Plant part used & Country & References \\
\hline Anemia & Bark & Lesotho & {$[70]$} \\
\hline Bladder problems & Bark & Lesotho & {$[71-74]$} \\
\hline Breast and cervical cancer & Leaves & Lesotho & {$[69,74]$} \\
\hline Cardiovascular problems & Bark & Lesotho & {$[70]$} \\
\hline Cleanses blood & Bark & Lesotho & {$[70]$} \\
\hline Colic & Bark & South Africa & {$[52,75,76]$} \\
\hline Dysmenorrhea & Bark & South Africa & {$[52,75,76]$} \\
\hline Emetic & Bark and leaves & Lesotho and Swaziland & {$[57,71-74]$} \\
\hline Heartburn & Bark & Lesotho & {$[70-73,77]$} \\
\hline $\begin{array}{l}\text { Human immunodeficiency virus } \\
\text { opportunistic infections }\end{array}$ & Bark and leaves & South Africa & {$[78-80]$} \\
\hline Immune booster & Bark, leaves, and roots & Lesotho and South Africa & {$[77-81]$} \\
\hline Intestinal ulcers & Leaves & Lesotho & {$[71-74,77]$} \\
\hline Intestinal parasites and worms & Bark, fruits, roots, and stems & Lesotho and South Africa & {$[70,82,83]$} \\
\hline Loss of appetite & Roots & Lesotho & [77] \\
\hline Malaria & Roots & South Africa & {$[78,79,84-86]$} \\
\hline Mental problems & Leaves & South Africa and Swaziland & {$[52,57,58,75,82,87,88]$} \\
\hline Nervous problems & Leaves & South Africa & {$[52,75,76,82,87,89]$} \\
\hline Phlegm & Bark & Lesotho & {$[70]$} \\
\hline Pellagra & Bark & Lesotho & {$[70]$} \\
\hline Purgative & Leaves & South Africa & {$[78,79]$} \\
\hline Rheumatism and swollen limbs & Leaves & South Africa & {$[75,76,90]$} \\
\hline Boils, shingles, and skin diseases & Bark and leaves & Lesotho and South Africa & {$[71-74,78-81]$} \\
\hline Indigestion and stomach complaints & Leaves and roots & Lesotho and South Africa & {$[71-74,77-79,84,91]$} \\
\hline Tonic & Bark and leaves & South Africa & {$[78-80]$} \\
\hline Sores and wounds & Bark and leaves & Lesotho and South Africa & {$[70-74,82,90,92]$} \\
\hline
\end{tabular}


activities of dichloromethane: methanol (1:1) leaf extracts of C. paniculata against sixty human cancer cell lines organized into subpanels representing leukemia, melanoma and cancer of the lung, colon, kidney, ovary, and central nervous system. The extracts exhibited activities against leukemia RPMI-8226, colon HCT-116, and colon KM12 with total growth inhibition (TGI) values of $1.0 \mu \mathrm{g} / \mathrm{ml}, 1.5 \mu \mathrm{g} / \mathrm{ml}$, and $2.7 \mu \mathrm{g} / \mathrm{ml}$, respectively [106].

\section{Anti-inflammatory activities}

Tetyana [52] and Tetyana et al. [75] evaluated anti-inflammatory activities of bark, leaves, roots, and stems ethanolic, ethyl acetate and water extracts of $C$. paniculata using the cyclooxygenase-1 (COX-1) assay. The extracts inhibited COX in the COX-1 assay with $85.0 \%$

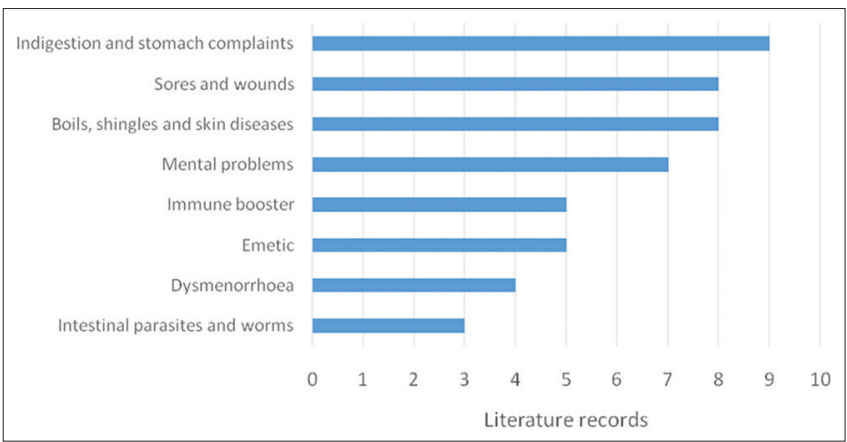

Fig. 1: Medicinal applications of Cussonia paniculata derived from literature records being the highest inhibition [52,75]. Adedapo et al. [95] evaluated the anti-inflammatory activities of aqueous extract of the stem bark of $C$. paniculata using the carrageenan-induced rat paw edema and histamine-induced rat paw edema assays with indomethacin and cyproheptadine as positive controls. The extract at $50 \mathrm{mg} / \mathrm{kg}$, $100 \mathrm{mg} / \mathrm{kg}$, and $200 \mathrm{mg} / \mathrm{kg}$ body weight reduced significantly, the formation of edema induced by carrageenan and histamine [95]

\section{Antiplasmodial activities}

Tetyana [52] and Tetyana et al. [75] evaluated antiplasmodial activities of the bark ethanolic, ethyl acetate and water extracts of $C$. paniculata against Plasmodium falciparum in an in vitro assay, a slightly modified version of the parasite lactate dehydrogenase assay with chloroquine as a positive control. The extracts exhibited weak inhibitory activities ranging from $10 \%$ to $35 \%$ at a concentration of $200 \mathrm{mg} / \mathrm{ml}[52,75]$. De Villiers et al. [104] evaluated antiplasmodial activities of aqueous and methanol leaf extracts of $C$. paniculata subsp. paniculata and $C$. paniculata subsp. sinuata using the $\left(\mathrm{G}^{-}{ }^{3} \mathrm{H}\right)$ hypoxanthine incorporation assay against the chloroquine-sensitive (3D7) strain of $P$. falciparum as the test organism. The extracts exhibited moderate antiplasmodial activities with half maximal inhibitory concentration $\left(\mathrm{IC}_{50}\right)$ value of $>50.0 \mathrm{mg} / \mathrm{mL}[104]$.

\section{Antiprotozoan activities}

De Villiers et al. [104] evaluated antiprotozoan activities of aqueous and methanol leaf extracts of $C$. paniculata subsp. paniculata and C. paniculata subsp. sinuata against protozoan pathogen associated with urogenital or sexually transmitted infections, Trichomonas vaginalis using the microplate bioassay with ciprofloxacin

Table 2: Phytochemical compounds identified from Cussonia paniculata leaves

\begin{tabular}{|c|c|}
\hline Phytochemical composition & References \\
\hline \multicolumn{2}{|l|}{ Acetylated triterpene glycosides } \\
\hline 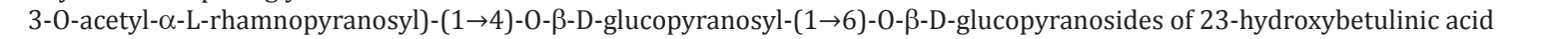 & [94] \\
\hline $\begin{array}{l}\text { 28-0-(2-0-acetyl- } \alpha \text {-L-rhamnopyranosyl)-(1 } \rightarrow 4)-0-\beta \text {-D-glucopyranosyl- }(1 \rightarrow 6)-0-\beta \text {-D-glucopyranosides of } 23 \text {-hydroxybetulinic } \\
\text { acid }\end{array}$ & [94] \\
\hline 28-0-(2-0-acetyl- $\alpha$-L-rhamnopyranosyl)-(1 $\rightarrow 4)-0-\beta$-D-glucopyranosyl- $(1 \rightarrow 6)-0-\beta$-D-glucopyranosides of hederagenin & [94] \\
\hline 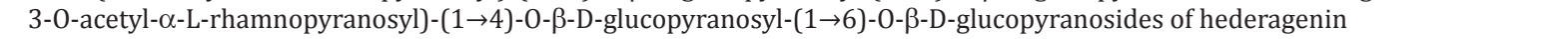 & [94] \\
\hline $\begin{array}{l}\text { 3-0- } \alpha \text {-L-arabinopyranosyl-28-0-(2-0-acetyl- } \alpha \text {-L-rhamnopyranosyl)-(1-4)-0- } \beta \text {-Dglucopyranosyl-(1 } \rightarrow 6)-0-\beta \text {-D-glycopyranosides } \\
\text { of oleanic acid }\end{array}$ & [94] \\
\hline 3-0-acetyl- $\alpha$-L-rhamnopyranosyl)-(1 $\rightarrow 4)-0-\beta$-Dglucopyranosyl- $(1 \rightarrow 6)-0-\beta$-D-glycopyranosides of oleanic acid & [94] \\
\hline $\begin{array}{l}\text { 3-0- } \alpha \text {-L-arabinopyranosyl-28-0-(2-0-acetyl- } \alpha \text {-L-rhamnopyranosyl)-(1 } \rightarrow 4)-0 \text { - } \beta \text {-Dglucopyranosyl-( } 1 \rightarrow 6)-0-\beta \text {-D-glycopyranosides } \\
\text { of ursolic acid }\end{array}$ & [94] \\
\hline 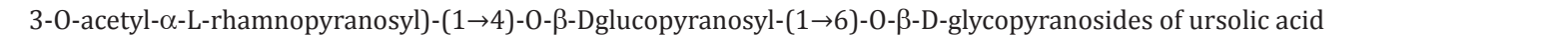 & [94] \\
\hline $\begin{array}{l}\text { 3-0- } \alpha \text {-L-arabinopyranosyl-28-0-(4-0-acetyl- } \alpha \text {-L-rhamnopyranosyl)-(1 } \rightarrow 4)-0 \beta \text {-D-glucopyranosyl-( } 1 \rightarrow 6)-0-\beta \text {-D-glucopyranosides } \\
\text { of hederagenin }\end{array}$ & [94] \\
\hline 2-0-acetyl- $\alpha$-L-rhamnopyranosyl)-(1 $\rightarrow 4)-0 \beta$-D-glucopyranosyl- $(1 \rightarrow 6)-0$ - $\beta$-D-glucopyranosides of hederagenin & [94] \\
\hline 3-0-acetyl- $\alpha$-L-rhamnopyranosyl)- $(1 \rightarrow 4)-0 \beta$-D-glucopyranosyl- $(1 \rightarrow 6)-0-\beta$-D-glucopyranosides of hederagenin & [94] \\
\hline 3 -0-acetyl- $\alpha$-L-rhamnopyranosyl)- $(1 \rightarrow 4)-0-\beta$-D-glucopyranosyl- $(1 \rightarrow 6)-0-\beta$-D-glucopyranosides of oleanic acid & [94] \\
\hline \multicolumn{2}{|l|}{ Unacetylated triterpene glycosides } \\
\hline 28-0- $\alpha$-L-rhamnopyranosyl-(1 $\rightarrow 4)-0-\beta$-D-glucopyranosyl- $(1 \rightarrow 6)-0-\beta$-D-glucopyranoside of 23 -hydroxyursolic acid & [93] \\
\hline 3-0- $\beta$-D-glucopyranoside of $\beta$-sitosterol & [93] \\
\hline 3-0- $\alpha$-L-arabinopyranosides of oleanolic acid & [93] \\
\hline 3-0- $\alpha$-L-arabinopyranosides of ursolic acid & [93] \\
\hline 3-0- $\alpha$-L-arabinopyranosides of hederagenin & [93] \\
\hline 3-0- $\beta$-D-glucopyranosyl- $(1 \rightarrow 2)$ - $\alpha$-L-arabinopyranoside of oleanolic acid & [93] \\
\hline $\begin{array}{l}\text { 3-0- } \alpha \text {-L-arabinopyranosyl-28-0- } \alpha \text {-L-rhamnopyranosyl- }(1 \rightarrow 4)-0-\beta \text {-D-glucopyranosyl- }(1 \rightarrow 6)-0 \text { - } \beta \text {-D-glucopyranosides of oleanolic } \\
\text { acid }\end{array}$ & [93] \\
\hline $\begin{array}{l}\text { 3-0- } \alpha \text {-L-arabinopyranosyl-28-0- } \alpha \text {-L-rhamnopyranosyl-(1-4)-0- } \beta \text {-D-glucopyranosyl- }(1 \rightarrow 6)-0-\beta \text {-D-glucopyranosides of ursolic } \\
\text { acid }\end{array}$ & [93] \\
\hline \multicolumn{2}{|l|}{ 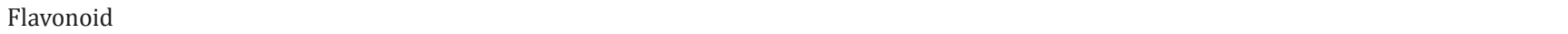 } \\
\hline Rutin & [76] \\
\hline \multicolumn{2}{|l|}{ Steroidal saponin } \\
\hline Pseudoprostodioscin & [76] \\
\hline Spinasaponin A & [76] \\
\hline
\end{tabular}


$(0.01 \mathrm{mg} / \mathrm{mL})$ as a positive control. Only methanol extract exhibited activities with MIC value of $1.0 \mathrm{mg} / \mathrm{mL}$ and $1.3 \mathrm{mg} / \mathrm{mL}$ against C. paniculata subsp. paniculata and $C$. paniculata subsp. sinuata extracts, respectively, and these values were higher than $0.001 \mathrm{mg} / \mathrm{mL}$ exhibited by the control [104].

\section{A $\beta 42$ protein reduction activities}

Thakur et al. [76] evaluated the $A \beta 42$ protein reduction activities of dichloromethane: methanol (1:1) leaf and stem extracts of $C$. paniculata using ELISA - sAPP $\alpha, s A P P \beta$, and A $\beta$ peptide assays. The extract reduced the secreted level of $A \beta 42$ in a dose-dependent manner compared to the control by $57.5 \%$. The extract also decreased the levels of $A \beta 40$, sAPP $\beta$-sw, and sAPP $\alpha$ in a dose-dependent manner [76].

\section{Cytotoxicity activities}

De Villiers et al. [104] evaluated cytotoxicity activities of aqueous and methanol leaf extracts of $C$. paniculata subsp. paniculata and C. paniculata subsp. sinuata against the human T-cell leukemia (Jurkat) cell line using the 3-(4,5-dimethylthiazol-2-yl)-2,5-diphenyl tetrazolium bromide calorimetric assay with (S)-(+)-camptothecin as a positive control. The extracts exhibited moderate cytotoxicity activities with $\mathrm{IC}_{50}$ values ranging from $26.5 \mathrm{mg} / \mathrm{mL}$ to $>50.0 \mathrm{mg} / \mathrm{mL}$ [104].

\section{Toxicity activities}

Adedapo et al. [95] evaluated acute toxicity activities of aqueous extract of the stem bark of $C$. paniculata by oral administration of graded doses of the extract of $200 \mathrm{mg} / \mathrm{kg}, 400 \mathrm{mg} / \mathrm{kg}, 800 \mathrm{mg} / \mathrm{kg}, 1600 \mathrm{mg} / \mathrm{kg}$, and $3200 \mathrm{mg} / \mathrm{kg}$ body weight in Wistar male rats. All the rats were allowed free access to food and water and observed over a period of $48 \mathrm{~h}$ for signs of acute toxicity and deaths within this period. Acute toxicity test showed that the extract caused $80 \%$ mortality in rats, and hence, C. paniculata can be regarded as toxic [95].

\section{CONCLUSION}

The diverse medicinal uses of $C$. paniculata documented in southern Africa, and the scientific evidence of its phytochemistry and biological activities indicates its potential as herbal medicine. However, there is a need for detailed phytochemical and pharmacological studies aimed at correlating its documented ethnomedicinal uses with the phytochemical and pharmacological properties of the species. There is a need for clinical and toxicological evaluations since preliminary acute toxicity studies by Adebapo et al. [95] indicated that aqueous extract of the stem bark of $C$. paniculata contains potentially toxic compounds. Therefore, future research should focus on the identification of toxic compounds, the possible side effects caused by taking $C$. paniculata as herbal medicine, and mechanisms of how potential toxic components of the species can be managed when the species is used as herbal medicine.

\section{ACKNOWLEDGMENTS}

I would like to express my gratitude to the National Research Foundation, South Africa and Govan Mbeki Research and Development Centre, University of Fort Hare for financial support to conduct this study.

\section{AUTHORS' CONTRIBUTIONS}

The author declares that this work was done by the author named in this article.

\section{CONFLICTS OF INTEREST}

The author declares that he has no conflict of interest.

\section{REFERENCES}

1. Attele AS, Wu JA, Yuan CS. Ginseng pharmacology: Multiple constituents and multiple actions. Biochem Pharmacol 1999;58:1685-93.

2. Choi KT. Botanical characteristics, pharmacological effects and medicinal components of Korean Panax ginseng C A Meyer. Acta Pharmacol Sin 2008;29:1109-18.

3. Yıldırım A, Erener G. The possibilities using of ginseng (Panax spp.) in poultry nutrition. Hasad J Anim Sci 2010;26:56-9.

4. Leung KW, Wong AS. Ginseng and male reproductive function. Spermatogenesis 2013;3:e26391.

5. Yıldırım A, Şekeroğlu A, Eleroğlu H, Şen MI, Duman M. Effects of Korean ginseng (Panax ginseng C.A. Meyer) root extract on egg production performance and egg quality of laying hens. S Afr J Anim Sci 2013;43:194-207.

6. Yang L, Yu QT, Ge YZ, Zhang WS, Fan Y, Ma CW, et al. Distinct urine metabolome after Asian ginseng and American ginseng intervention based on GC-MS metabolomics approach. Sci Rep 2016;6:39045.

7. Li TSC, Mazza G, Cottrell AC, Gao L. Ginsenosides in roots and leaves of American ginseng. J Agr Food Chem 1996;44:717-20.

8. Vuksan V, Sievenpiper JL, Koo VY, Francis T, Beljan-Zdravkovic U, Xu Z, et al. American ginseng (Panax quinquefolius L) reduces postprandial glycemia in nondiabetic subjects and subjects with Type 2 diabetes mellitus. Arch Intern Med 2000;160:1009-13.

9. Vuksan V, Sievenpiper JL, Wong J, Xu Z, Beljan-Zdravkovic U, Arnason JT, et al. American ginseng (Panax quinquefolius L.) attenuates postprandial glycemia in a time-dependent but not dose-dependent manner in healthy individuals. Am J Clin Nutr 2001;73:753-8.

10. Stavro PM, Woo M, Heim TF, Leiter LA, Vuksan V. North American ginseng exerts a neutral effect on blood pressure in individuals with hypertension. Hypertension 2005;46:406-11.

11. Scholey A, Ossoukhova A, Owen L, Ibarra A, Pipingas A, He K, et al. Effects of American ginseng (Panax quinquefolius) on neurocognitive function: An acute, randomised, double-blind, placebo-controlled, crossover study. Psychopharmacology (Berl) 2010;212:345-56.

12. Lui EM, Azike CG, Guerrero-Analco JA, Romeh AA, Pei H, Kaldas SJ, et al. Bioactive polysaccharides of American ginseng Panax quinquefolius L. in modulation of immune function: Phytochemical and pharmacological characterization. In: Karunaratne DN, editor. The Complex World of Polysaccharides. London: IntechOpen; 2012. p. 513-34.

13. Jiang M, Murias JM, Chrones T, Sims SM, Lui E, Noble EG, et al. American ginseng acutely regulates contractile function of rat heart. Front Pharmacol 2014;5:43.

14. Erdle SC, Chan ES, Yang H, Vallance BA, Mill C, Wong T, et al. First-reported pediatric cases of American ginseng anaphylaxis and allergy. Allergy Asthma Clin Immunol 2018;14:79.

15. Lui JH, Staba EJ. The ginsenosides of various ginseng plants and selected products. J Nat Prod 1980;43:340-6.

16. Radad K, Gille G, Irausch WD. Use of ginseng in medicine: Perspectives on CNS disorders. Iran J Pharmacol Ther 2004;3:30-40.

17. Chan HH, Hwang TL, Reddy MV, Li DT, Qian K, Bastow KF, et al. Bioactive constituents from the roots of Panax japonicus var. Major and development of a LC-MS/MS method for distinguishing between natural and artifactual compounds. J Nat Prod 2011;74:796-802.

18. Lee OR, Han JH, Kim Y. Agrobacterium-mediated transformation of mature ginseng embryos. Bio-protocol 2014;4:e1362.

19. Rai A, Yamazaki M, Takahashi H, Nakamura M, Kojoma M, Suzuki H, et al. RNA-seq transcriptome analysis of Panax japonicus, and its comparison with other Panax species to identify potential genes involved in the saponins biosynthesis. Front Plant Sci 2016;7:481.

20. Agarwal H, Gayathri M. Biological synthesis of nanoparticles from medicinal plants and its uses in inhibiting biofilm formation. Asian J Pharm Clin Res 2017;10:64-8.

21. Manzanilla V, Kool A, Nguyen Nhat L, Nong Van H, Le Thi Thu H, de Boer HJ, et al. Phylogenomics and barcoding of Panax: Toward the identification of ginseng species. BMC Evol Biol 2018;18:44.

22. Pennisi BV, Oetting RD, Stegelin FE, Thomas PA, Woodward JL. Commercial production of English ivy (Hedera helix L.). Athens Bulletin 1206. Georgia: University of Georgia; 2009.

23. Saiah H, Allem R, El Kebir FZ. Antioxidant and antibacterial activities of six Algerian medicinal plants. Int J Pharm Pharm Sci 2016;8:367-74

24. Small E. Ivy (Hedera species): Virtues and vices of the world's most popular ornamental vine. Biodiversity 2019;20:62-74.

25. Hofmann D, Hecker M, Völp A. Efficacy of dry extract of ivy leaves in children with bronchial asthma-a review of randomized controlled trials. Phytomedicine 2003;10:213-20.

26. Bolbot Y, Prokhorov E, Mokia S, Yurtseva A. Comparing the efficacy and safety of high concentrate (5-7.5:1) ivy leaves extract and 
acetylcysteine for treatment of children with acute bronchitis. Drugs Ukraine 2004;11:1-4.

27. Lutsenko Y, Bylka W, Matławska I, Darmohray R. Hedera helix as a medicinal plant. Herba Pol 2010;56:83-96.

28. Holzinger F, Chenot JF. Systematic review of clinical trials assessing the effectiveness of ivy leaf (Hedera helix) for acute upper respiratory tract infections. Evid Based Complement Alternat Med 2011;2011:382789.

29. Rai A. The antiinflammatory and antiarthritic properties of ethanol extract of Hedera helix. Indian J Pharm Sci 2013;75:99-102.

30. Rehman SU, Kim IS, Choi MS, Kim SH, Zhang Y, Yoo HH, et al. Time-dependent inhibition of CYP2C8 and CYP2C19 by Hedera helix extracts, a traditional respiratory herbal medicine. Molecules 2017;22:e1241.

31. Al-Snafi AE. Pharmacological and therapeutic activities of Hedera helix: A review. IOSR J Pharm 2018;8:41-53.

32. Yu M, Liu J, Li L, Xu H, Xing Y, Zhao Y, et al. Pharmacokinetic parameters of three active ingredients hederacoside $\mathrm{C}$, hederacoside $\mathrm{D}$, and $\Theta$-hederin in Hedera helix in rats. J Sep Sci 2016;39:3292-301.

33. Elias R, De Méo M, Vidal-Ollivier E, Laget M, Balansard G, Dumenil G, et al. Antimutagenic activity of some saponins isolated from Calendula officinalis L. C. arvensis L. And Hedera helix L. Mutagenesis 1990;5:327-31.

34. Trute A, Gross J, Mutschler E, Nahrstedt A. In vitro antispasmodic compounds of the dry extract obtained from Hedera helix. Planta Med $1997 ; 63: 125-9$

35. Villani P, Orsiere T, Sari-Minodier I, Bouvenot G, Botta A. In vitro study of antimutagenic activity of alpha hederin. Ann Biol Clin (Paris) 2001;59:285-9.

36. Barthomeuf C, Debiton E, Mshvildadze V, Kemertelidze E, Balansard G. In vitro activity of hederacolchisid A1 compared with other saponins from Hedera colchica against proliferation of human carcinoma and melanoma cells. Planta Med 2002;68:672-5.

37. Süleyman H, Mshvildadze V, Gepdiremen A, Elias R. Acute and chronic antiinflammatory profile of the ivy plant, Hedera helix, in rats. Phytomedicine 2003;10:370-4

38. Gülçin I, Mshvildadze V, Gepdiremen A, Elias R. Antioxidant activity of saponins isolated from ivy: Alpha-hederin, hederasaponin-C, hederacolchiside-E and hederacolchiside-F. Planta Med 2004;70:561-3

39. Pop CE, Pârvu M, Arsene AL, Pârvu AE, Vodnar DC, Tarcea M, et al. Investigation of antioxidant and antimicrobial potential of some extracts from Hedera helix L. Farmacia 2017;65:624-9.

40. Reyneke WF. A new species of Cussonia (Araliaceae) from the Transvaal. S Afr J Bot 1984;3:368-74.

41. Reyneke WF, Kok PD. Two varieties of Cussonia paniculata Eckl. and Zeyh. (Araliaceae). S Afr J Bot 1987;53:317-22.

42. Tetyana P, Van Staden J. Micropropagation of Cussonia paniculata: A medicinal plant with horticultural potential. S Afr J Bot 2001;68:51-4.

43. Retief E, Meyer NL. Plants of the Free State Inventory and Identification Guide. Pretoria: Strelitzia 38, South African National Botanical Institute; 2017.

44. De Villiers BJ, Plunkett GM, Tilney PM, Van Wyk BE. A phylogenetic study of the genus Cussonia (Araliaceae) based on morphological, anatomical and molecular data. S Afr J Bot 2009;75:398.

45. De Villiers BJ, Tilney PM, Van Wyk BE. The taxonomic significance of leaf anatomical characters in Cussonia and related genera (Araliaceae). Bot J Linnean Soc 2010;164:246-63.

46. De Villiers BJ, Oskolski AA, Tilney PM, Van Wyk BE. Wood anatomy of Cussonia and Seemannaralia (Araliaceae) with systematic and ecological implications. IAWA J 2012;33:163-86.

47. Palmer E, Pitman P. Trees for Southern Africa Covering all known Indigenous Species in Republic of South Africa, South West Africa, Botswana, Lesotho and Swaziland. Cape Town: A.A. Balkema; 1972.

48. Barkhuizen BP. The Cycad Garden of Unisa. Pretoria: University of South Africa; 1975.

49. Oliver IB. Cultivation of the mountain cabbage tree: Cussonia paniculata Eckl. and Zeyh. var. sinuate Reyneke. Veld Fl 1987; $73: 135-6$

50. Walker CC, Levers M. Cussonia paniculata: The mountain cabbage tree. Br Cactus Succ J 1988;98-100.

51. Joffe P. The Gardener's Guide to South African Plants. Cape Town: Delos; 1993.

52. Tetyana P. Medicinal Properties and Micropropagation of Cussonia species. MSc Dissertation. Pietermaritzburg: University of Natal; 2000
53. Ogden S, Ogden LS. Plant-Driven Design: Creating Gardens that Honor Plants, Place, and Spirit. London: Timber Press; 2008.

54. Moyo M, Bairu MW, Amoo SO, Van Staden J. Plant biotechnology in South Africa: Micropropagation research endeavours, prospects and challenges. S Afr J Bot 2011;77:996-1011.

55. Richard S. The New Ornamental Garden. Collingwood: Csiro Publishing Gardening Guides; 2011.

56. Davoren E. Plant Diversity Patterns of Domestic Gardens in Five Settlements of South Africa. PhD Thesis. Potchefstroom: North-West University; 2017.

57. Long C. Swaziland's Flora: SiSwati Names and Uses; 2005. Swaziland National Trust Commission, Mbambane. Available from: http://www.sntc.org.sz/index.asp. [Last accessed on 2017 May 20].

58. Van Wyk BE, Gericke N. People's Plants: A Guide to Useful Plants of Southern Africa. Pretoria: Briza Publications; 2007.

59. Welcome AK, Van Wyk BE. An inventory and analysis of the food plants of Southern Africa. S Afr J Bot 2019;122:136-79.

60. Makunga NP, Philander LE, Smith M. Current perspectives on an emerging formal natural products sector in South Africa. J Ethnopharmacol 2008;119:365-75.

61. Dovie DB, Witkowski ET, Shackleton CM. Knowledge of plant resource use based on location, gender and generation. Appl Geogr 2008;28:311-22.

62. Stafleu FA, Cowan RS. Taxonomic Literature. Utrechst: Scheltema and Holkema; 1976.

63. Gavhi P, Harris S, Reynolds Y. Cussonia paniculata Eckl and Zeyh; 2002. Available from: http://www.pza.sanbi.org/cussonia-paniculata. [Last accessed on 2017 May 20].

64. Germishuizen G, Meyer NL. Plants of Southern Africa: An Annotated Checklist. Pretoria: Strelitzia 14, National Botanical Institute; 2003.

65. Cannon JF. Araliaceae. In: Launert E, editor. Flora Zambesiaca. Vol. 4. London: Flora zambesiaca Managing Committee; 1978. p. 621-32.

66. Van Wyk B, Van Wyk P. Field Guide to Trees of Southern Africa. Cape Town: Struik; 1997

67. Palgrave MC. Keith Coates Palgrave Trees of Southern Africa. Cape Town: Struik Publishers; 2002

68. Manning JC, Goldblatt P. Plants of the Greater Cape Floristic Region 1: The Core Cape Flora. Cape Town: Strelitzia 29, South African National Biodiversity Institute; 2012.

69. Moteetee A, Seleteng Kose L. Medicinal plants used in Lesotho for treatment of reproductive and post reproductive problems. J Ethnopharmacol 2016;194:827-49.

70. Mugomeri E, Chatanga P, Raditladi T, Makara M, Tarirai C. Ethnobotanical study and conservation status of local medicinal plants: Towards a repository and monograph of herbal medicines in Lesotho. Afr J Tradit Complement Altern Med 2016;13:143-56.

71. Guillarmod AJ. Flora of Lesotho. Lehre: Cramer; 1971

72. Maliehe EB. Medicinal Plants and Herbs of Lesotho. Maseru: Mafeteng Development Project; 1997.

73. Moteetee A, Van Wyk BE. The medical ethnobotany of Lesotho: A review. Bothalia 2011;41:209-28

74. Seleteng Kose L, Moteetee A, Van Vuuren S. Ethnobotanical survey of medicinal plants used in the Maseru district of Lesotho. J Ethnopharmacol 2015; 170:184-200.

75. Tetyana P, Van Staden J. Micropropagation of Cussonia paniculata: A medicinal plant with horticultural potentials. S Afr J Bot 2001;67:367-70

76. Thakur A, Chun YS, October N, Yang HO, Maharaj V. Potential of South African medicinal plants targeting the reduction of a $\beta 42$ protein as a treatment of Alzheimer's disease. J Ethnopharmacol 2019;231:363-73.

77. Mugomeri E, Chatanga P, Chakane N. Medicinal herbs used by HIVpositive people in Lesotho. Afr J Tradit Complement Altern Med 2016;13:123-31

78. Davids D. Materiamedica and Care: A Study of the Uses of Medicinal Herbs and Remedies as a form of Treatment and Negotiating Social Relationships in Cape Town and Surroundings. MSc Dissertation. Cape Town: University of the Western Cape; 2012.

79. Davids D, Blouws T, Aboyade O, Gibson D, De Jong JT, Klooster CV, et al. Traditional health practitioners' perceptions, herbal treatment and management of HIV and related opportunistic infections. J Ethnobiol Ethnomed 2014;10:77

80. Gail H, Tarryn B, Oluwaseyi A, Denver D, Oluchi M, Charlotte VK, et al. An ethnobotanical survey of medicinal plants used by traditional health practitioners to manage HIV and its related opportunistic infections in Mpoza, Eastern Cape Province, South Africa. 
J Ethnopharmacol 2015;171:109-15.

81. Maroyi A. Diversity of use and local knowledge of wild and cultivated plants in the Eastern Cape province, South Africa. J Ethnobiol Ethnomed 2017;13:43.

82. Watt JM, Breyer-Brandwijk MG. The Medicinal and Poisonous Plants of Southern and Eastern Africa. Edinburgh: E and S Livingstone; 1962.

83. Cock IE, Selesho MI, Van Vuuren SF. A review of the traditional use of Southern African medicinal plants for the treatment of selected parasite infections affecting humans. J Ethnopharmacol 2018;220:250-64

84. Schmidt E, Lotter M, McCleland W. Trees and Shrubs of Mpumalanga and Kruger National Park. Johannesburg: Jacana Media; 2002.

85. Afolayan AJ, Adebola PO. In vitro propagation: A biotechnological tool capable of solving the problem of medicinal plants decimation in South Africa. Afr J Biotech 2004;3:683-7.

86. Pillay P, Maharaj VJ, Smith PJ. Investigating South African plants as a source of new antimalarial drugs. J Ethnopharmacol 2008;119:438-54.

87. Sobiecki JF. A preliminary inventory of plants used for psychoactive purposes in southern African healing traditions. Trans Royal Soc S Afr 2002;57:1-24

88. Masondo NA, Stafford GI, Aremu AO, Makunga NP. Acetylcholinesterase inhibitors from Southern African plants: An overview of ethnobotanical, pharmacological potential and phytochemical research including and beyond Alzheimer's disease treatment. S Afr J Bot 2019;120:39-64

89. Alharbi R. Medicinal Properties of the Araliaceae, with Emphasis on Chemicals Affecting Nerve Cells. Masters Dissertation. Charleston: Eastern Illinois University; 2019.

90. Komoreng L, Thekisoe O, Lehasa S, Tiwani T, Mzizi N, Mokoena N, et al. An ethnobotanical survey of traditional medicinal plants used against lymphatic filariasis in South Africa. S Afr J Bot 2017;111:12-6.

91. Semenya SS, Potgieter MJ, Tshisikhawe MP. Use, conservation and present availability status of ethnomedicinal plants of Matebelevillage in the Limpopo Province, South Africa. Afr J Biotechnol 2013; 12:2392-405.

92. Moteetee A, Seleteng-Kose L. A review of medicinal plants used by the Basotho for treatment of skin disorders: Their phytochemical, antimicrobial, and anti-inflammatory potential. Afr $\mathrm{J}$ Tradit Complement Altern Med 2017;14:121-37.

93. Dovgii II, Grishkovets VI, Kachala VV, Shashkov AS. Triterpene glycosides from Cussonia paniculata: Isolation and structure determination of glycosides A, B1, B2, C,D, G2, HI and H2 from leaves of Cussonia paniculata. Chem Nat Comp 2005;41:200-4.

94. Grishkovets VI, Dovgii II, Kachala VV, Shashkov AS. Triterpene glycosides from Cussonia paniculata. II. Acetylated glycosides from leaves. Chem Nat Comp 2005;41:436-41.

95. Adedapo AA, Sofidiya MO, Maphosa V, Moyo B, Masika PJ, Afolayan AJ. Anti-inflammatory and analgesic activities of the aqueous extract of Cussonia paniculata stem bark. Rec Nat Prod 2008;2:46-53.

96. Panche AN, Diwan AD, Chandra SR. Flavonoids: An overview. J Nutr Sci 2016;5:e47.

97. Careaga VP, Bueno C, Muniain C, Alché L, Maier MS. Antiproliferative, cytotoxic and hemolytic activities of a triterpene glycoside from Psolus patagonicus and its desulfated analog. Chemotherapy 2009;55:60-8.

98. Bahrami Y, Franco CM. Acetylated triterpene glycosides and their biological activity from Holothuroidea reported in the past six decades. Mar Drugs 2016;14:e147.

99. Güçlü-Ustündağ O, Mazza G. Saponins: Properties, applications and processing. Crit Rev Food Sci Nutr 2007;47:231-58.

100. Thakur M, Melzig MF, Fuchs H, Weng A. Chemistry and pharmacology of saponins: Special focus on cytotoxic properties. Bot Targets Ther 2011;1:19-29.

101. Moses T, Papadopoulou KK, Osbourn A. Metabolic and functional diversity of saponins, biosynthetic intermediates and semi-synthetic derivatives. Crit Rev Biochem Mol Biol 2014;49:439-62.

102. Kregiel D, Berlowska J, Witonska I, Antolak H, Proestos C, Babic M, et al. Saponin-based, biological-active surfactants from plants. In: Najjar R. Application and Characterization of Surfactants. London: IntechOpen; 2017. p. 183-205.

103. Tian LW, Zhang Z, Long HL, Zhang YJ. Steroidal saponins from the genus Smilax and their biological activities. Nat Prod Bioprospect 2017:7:283-98

104. De Villiers BJ, Van Vuuren SF, Van Zyl RL, Van Wyk BE. Antimicrobial and antimalarial activity of Cussonia species (Araliaceae). J Ethnopharmacol 2010;129:189-96.

105. Fouché G, Khorombi E, Kolesnikova N, Maharaj VJ, NthambeleniR, Van der Merwe M. Investigation of South African plants for anticancer properties. Pharmacologyonline 2006;3:494-500.

106. Fouche G, Cragg GM, Pillay P, Kolesnikova N, Maharaj VJ, Senabe J, et al. In vitro anticancer screening of South African plants. J Ethnopharmacol 2008;119:455-61. 